\title{
Renal mechanisms in the cardiovascular effects of chronic exposure to inorganic mercury in rats
}

\author{
Marco Carmignani, Paolo Boscolo, Luciano Artese, Goffredo Del Rosso, Giovanni Porcelli, \\ Mario Felaco, Anna Rita Volpe, Giovanni Giuliano
}

\begin{abstract}
Male weanling Wistar rats received $200 \mu \mathrm{g} / \mathrm{ml}$ of mercury $(\mathbf{H g})$, as $\mathrm{HgCl}_{2}$, in drinking water for 180 days. At the end of the treatment, systemic arterial blood pressure was augmented, cardiac inotropism was reduced, and heart rate was unchanged. Light and electron microscopical studies of the kidney showed a mesangial proliferative glomerulonephritis in about $80 \%$ of the glomeruli. Tubular cells showed reduction of the acid phosphatase activity, which was related to functional abnormalities of the lysosomes. In the 24 hour urine samples of the $\mathrm{Hg}$ exposed rats, there was slight reduction of kallikrein activity, but evident proteinuria was not present in all samples. Plasma renin activity was reduced, that of angiotensin I-converting enzyme was augmented, and plasma aldosterone concentrations were unchanged. Mercury was accumulated mostly in the kidney of the $\mathrm{Hg}$ treated animals; and the content of $\mathrm{Hg}$ in the heart was higher than in the brain. These data show that chronic exposure to $\mathrm{Hg}$ acts on the kidney with complex mechanisms of toxicity; these contribute to modify systemic haemodynamics.
\end{abstract}

Department of Cell Biology and Physiology, University of L'Aquila, 67100 Coppito, Italy

$M$ Carmignani

Institute of Occupational Medicine, G D'Annunzio University, 66100 Chieti, Italy

P Boscolo

Institute of Human Pathology and Social Medicine

L Artese

Institute of Nephrology

G Del Rosso

Institute of Biology and Genetics

$M$ Felaco

Institute of Pharmacology, Catholic University, 00168 Rome, Italy

M Carmignani, G Porcelli, A R Volpe

Institute of Occupational Medicine, University of Florence, 50100 Florence, Italy

G Giuliano
Epidemiological and clinical studies have shown increased incidence of arterial hypertension and nephropathy with proteinuria and enzymuria in mercury $(\mathbf{H g})$ exposed workers. ${ }^{1-6}$ Although it was found that the kidney has a greater capacity than other organs to accumulate $\mathbf{H g}^{78}$ there is, however, no experimental evidence that renal storage of $\mathrm{Hg}$ activates mechanisms of toxicity leading to arterial hypertension or cardiovascular disorders.

Animal studies have found that chronic exposure to inorganic $\mathrm{Hg}$ affects some mechanisms regulating cardiovascular homeostasis. Male Sprague-Dawley rats, treated with $50 \mu \mathrm{g} / \mathrm{ml} \mathrm{Hg}$ as mercuric chloride $\left(\mathrm{HgCl}_{2}\right)$ in drinking water for 320 or 350 days, showed an increase in cardiac inotropism, hyporeactivity of baroreflex mechanisms, and changes in cardiovascular reactivity after stimulation of the peripheral $\alpha$ - or $\beta$-adrenoreceptors ${ }^{7-9}$; arterial blood pressure was significantly increased only in the rats exposed to the metal for 350 days. ${ }^{89}$ These findings suggested that $\mathrm{Hg}$ interferes with both influx and intracellular availability of calcium ions $\left(\mathrm{Ca}^{2+}\right)$ for contractile mechanisms in cardiac and vascular myocells by an action on receptor operated $\mathrm{Ca}^{2+}$ channels in the plasma membrane and on cyclic nucleotide pathways. Light and electron microscopical observation of the kidneys of these rats showed lysis of lysosomes in the tubular cells and minor morphological alterations in the glomeruli (segmental thickening of the basal membrane with corresponding focal fusion of foot processes). ${ }^{9}$

In a recent experiment, male Wistar rats received 50 or $200 \mu \mathrm{g} / \mathrm{ml}$ of $\mathrm{Hg}$ (as $\mathrm{HgCl}_{2}$ ) in the drinking water for 350 days from weaning. Blood pressure was increased in the rats exposed to both doses of $\mathrm{Hg}$, whereas cardiac inotropism was augmented only in the animals exposed to the lower dose. ${ }^{10}{ }^{11}$ Exposure to $\mathrm{Hg}$ specifically reduced cardiovascular reactivity to stimulation of either baroreceptors or cardiac and vascular $\alpha_{1}$-adrenoreceptors; there was also an increase of the effects after activation of the cardiovascular $\mathrm{DA}_{2}$-dopaminergic and $\beta_{1}$ - and $\beta_{2}$-adrenergic receptors. Light microscopical observation of the kidney showed glomerulonephritic lesions in $30 \%$ of the glomeruli of the rats exposed to $50 \mathrm{ppm}$ 
$\mathrm{Hg}$ and in almost all the glomeruli of the animals treated with $200 \mathrm{ppm} \mathrm{Hg}$; in the glomeruli thickening of the basal membrane and hypercullularity with proliferation of the mesangial matrix were found; in the tubuli, there was hydropic degeneration of the cells and some casts. ${ }^{1011}$

Other experimental studies have confirmed that subacute or chronic exposure to $\mathrm{Hg}$, at doses able to affect cardiovascular function, may induce renal alterations. For example, Wistar rats, treated with doses of inorganic $\mathrm{Hg}$ that ranged from 50 to $200 \mu \mathrm{g} /$ $100 \mathrm{~g}$ body weight by subcutaneous route three times a week for a period of two to 10 months, showed a membranous glomerulonephritis. ${ }^{12}$ In another study, Wistar rats that received $150 \mu \mathrm{g}$ of $\mathrm{HgCl}_{2}$ per $100 \mathrm{~g}$ body weight by subcutaneous injection three times a week for 27 weeks showed a mesangial glomerulonephritis with deposition of $\operatorname{IgG}, \operatorname{IgM}$, and complement component $\mathrm{C}_{3}$ in the mesangium. ${ }^{13}$ Other strains of rats treated with $\mathrm{HgCl}_{2}$ presented different immunological alterations dependent upon genetic variables. ${ }^{14}$ Brown Norway rats, treated with different doses of $\mathrm{HgCl}_{2}$ for different periods, had autoimmune abnormalities that included lymphoproliferation, production of antiglomerular basement membrane and anti-DNA antibodies, increased serum IgE concentrations, and polyclonal increase in total IgG concentration, as well as circulating immune complexes. On the basis of these results, it was suggested that $\mathrm{Hg}$ stimulates autoreactive T-helper cells, inhibits $T$-suppressor cells, and induces polyclonal activation of $\beta$-lymphocyte cells. After the initial period of exposure there was spontaneous remission of these changes, which suggests that the $T$-suppressor cells may recover from inhibition and regulate the $\mathrm{Hg}$ induced autoimmune responses. On the other hand, Lewis rats, treated with $\mathrm{HgCl}_{2}$ in experimental protocols similar to those of the studies on Brown Norway rats, showed impaired regulation of immunological function and immunosuppression. ${ }^{14} 15$ Finally, rabbits and mice treated with $\mathrm{HgCl}_{2}$ showed several autoimmune disorders and glomerulonephritis. ${ }^{14}$

The purpose of this study was to investigate some mechanisms of renal toxicity possibly involved in the dysfunction of cardiovascular function, in rats exposed to doses of $\mathrm{Hg}$ known to induce both arterial hypertension and autoimmune lesions in the kidney.

\section{Materials and methods}

Sixteen male weanling Wistar rats were randomly divided into two equal groups, housed in stainless steel cages, and fed a standard laboratory diet. One group received $200 \mu \mathrm{g} / \mathrm{ml}$ of $\mathrm{Hg}$ (as $\mathrm{HgCl}_{2}$ ) in deionised drinking water for 180 days and the other group was kept as a control. At the end of the exposure all the rats were placed in metabolism cages for the collection of 24 hour urine samples.
The animals were anaesthetised with a single intraperitoneal injection of sodium thiopental ( 50 $\mathrm{mg} / \mathrm{kg}$ body weight) in order to perform haemodynamic measurements. The trachea was cannulated to allow spontaneous breathing and polyethylene catheters (containing sodium heparin, 100 USP units $/ \mathrm{ml}$ ) were placed in the left femoral artery to record aortic blood pressure. Systolic and diastolic blood pressure were measured by means of a P23Db Statham pressure transducer (Statham Medical Instruments, Los Angeles, CAL) and averaged electronically. A Biotronex BL 620 derivative computer (Biotronex Laboratories, Inc., Kensington, MA) was used for determining the maximum rate of rise of the left ventricular isovolumetric pressure $(\mathrm{dP} / \mathrm{dt})$, an index of cardiac inotropism. In this regard, a calibrated $3 \mathrm{~F}$ catheter tip pressure transducer (Millar Instruments, Houston, TX), inserted in the right common carotid artery and advanced in the left ventricle, was used to determine $\mathrm{dP} / \mathrm{dt} .^{1011}$ The computer was adjusted to minimise the expression of preload and afterload according to Crawford $e t a l^{16}$ and Davidson et al. ${ }^{17}$ Heart rate was measured by a Beckman cardiotachometer coupler, which was triggered by an R-peak of the lead II electrocardiogram. The cardiovascular parameters were continously monitored on a Beckman type RM Dynograph recorder (Beckman Instruments, Inc, Schiller Park, ILL) after stabilisation for 30 minutes.

Blood samples were collected from the left common carotid artery for determining plasma renin activity (PRA) ${ }^{18}$ plasma angiotensin I-converting enzyme (ACE) activity, ${ }^{19}$ and plasma aldosterone concentrations ${ }^{20}$ Kallikrein activity, ${ }^{21}$ and creatinine, total protein, sodium, potassium, and calcium concentrations were determined in the 24 hour urine samples.

Samples of renal tissue were snap frozen in liquid nitrogen for histochemical and immunofluorescence examination; cryostat sections were prepared from these samples for demonstrating acid phosphatase activity by the method of Gomori. ${ }^{22}$ Sections $3 \mu \mathrm{m}$ thick were cut in a cryostat, acetone fixed, washed in phosphate buffer solution (PBS, $\mathrm{pH} 7 \cdot 4$ ), and stained with monospecific antisera to IgA, IgG, IgM, $C_{3}, C_{1 d}$, albumin, and fibrinogen (Boehringer Mannheim Biochemica, Mannheim, Germany), washed in PBS, and mounted in buffered glycerine. ${ }^{23}$ Other renal samples were excised for light and electron microscopical observation, as previously described. ${ }^{24}$ Specimens of several tissues were also excised for histopathological observation by light microscopy.

Samples of blood, brain, heart, and kidney were prepared for determination of $\mathrm{Hg}$ content. Mercury was analysed by flameless atomic spectrophotometry after special digestion of tissues and blood. ${ }^{25} \mathrm{The} \mathrm{Hg}$ content was quoted as the wet weight of blood and tissues. 
Data were compared by Student's $t$ test. Results were considered significant at $\mathrm{p}<0.05$.

\section{Results}

Body weight and general appearance of the animals were not affected by $\mathrm{Hg}$ exposure. In the $\mathrm{Hg}$ exposed rats, systolic and diastolic blood pressure were significantly increased, whereas $\mathrm{dP} / \mathrm{dt}$ was reduced and heart rate was unchanged (table 1 ).

In the $\mathrm{Hg}$ treated animals plasma renin activity (PRA) was decreased, plasma ACE activity augmented, and plasma aldosterone concentrations were unmodified compared with the control rats (table 2). Moreover, urinary kallikrein activity and urinary creatinine concentration were slightly but significanily reduced after exposure to $\mathrm{Hg}$. Proteinuria was evident only in some of the $\mathrm{Hg}$ exposed rats. Concentrations of 24 hour urinary sodium, potassium, and calcium were similar to those of the controls (table 3 ).

Table 1 Blood pressure, heart rate, and maximum rate of rise of left ventricular isovolumetric pressure $(d P / d t)$ in rats chronically exposed to $\mathrm{Hg}$

\begin{tabular}{lcl}
\hline & $\begin{array}{l}\text { Control }(n=8) \\
(\text { mean }(S E))\end{array}$ & $\begin{array}{l}\text { Exposed }(n=8) \\
(\text { mean }(S E))\end{array}$ \\
\hline Systolic pressure (mm Hg) & $131(6)$ & $151(3)^{\star}$ \\
Diastolic pressure (mm Hg) & $96(7)$ & $123(6)^{\star}$ \\
Heart rate (beats min) & $242(18)$ & $248(25)$ \\
dP dt (mm Hg/s) & $4421(332)$ & $3066(227)$ \\
\hline
\end{tabular}

*Significantly different from control, $p<0.05$.

Table 2 Plasma renin activity (PRA), plasma angiotensin I-converting enzyme ( $A C E$ ) activity, and plasma aldosterone concentration in rats chronically exposed to $\mathrm{Hg}$

\begin{tabular}{lcc}
\hline & $\begin{array}{l}\text { Control } \\
\text { (mean }(S E))\end{array}$ & $\begin{array}{l}\text { Exposed } \\
\text { (mean }(S E))\end{array}$ \\
\hline PRA $(\mathrm{ng} / \mathrm{ml} / \mathrm{h})$ & $33 \cdot 3(3 \cdot 2)$ & $16 \cdot 9(6 \cdot 0)^{\star}$ \\
Plasma ACE $(\mathrm{nmole} / \mathrm{ml})$ & $0 \cdot 14(0 \cdot 1)$ & $0 \cdot 30(0 \cdot 1)^{\star}$ \\
Plasma aldosterone $(\mathrm{pg} / \mathrm{ml})$ & $491(112)$ & $453(103)$ \\
\hline
\end{tabular}

${ }^{\star} \mathrm{p}<0.05$; significantly different from control.

For both groups $n=6$ for PRA and ACE, and $n=4$ for plasma aldosterone.

Table 3 Twenty four hour urinary kallikrein activity and creatinine, urea nitrogen, protein, sodium, potassium, and calcium concentrations in rats chronically exposed to $\mathrm{Hg}$

\begin{tabular}{lcc}
\hline & $\begin{array}{c}\text { Control }(n=8) \\
(\text { mean }(S E))\end{array}$ & $\begin{array}{c}\text { Exposed }(n=8) \\
\text { (mean }(S E))\end{array}$ \\
\hline Kallikrein (mamidolitic U) & $6070(550)$ & $4500(370)^{\star}$ \\
Creatinine $(\mu \mathrm{g})$ & $17 \cdot 8(1 \cdot 2)$ & $13 \cdot 0(1 \cdot 8)^{\star}$ \\
Urea nitrogen $(\mu \mathrm{g})$ & $386(45)$ & $358(49)$ \\
Protein $(\mathrm{mg})$ & $8 \cdot 4(1 \cdot 4)$ & $26 \cdot 4(16 \cdot 2)$ \\
Sodium $(\mathrm{mEq})$ & $1 \cdot 2(0 \cdot 05)$ & $1 \cdot 4(0 \cdot 1)$ \\
Potassium $(\mathrm{mEq})$ & $1.3(0 \cdot 1)$ & $1.4(0 \cdot 1)$ \\
Calcium $(\mu \mathrm{g})$ & $1 \cdot 4(0 \cdot 3)$ & $1 \cdot 1(0 \cdot 2)$ \\
\hline
\end{tabular}

${ }^{\star} \mathrm{p}<0 \cdot 05$; significantly different from control.
Light microscopical observation showed alterations in about $80 \%$ of the glomeruli of the $\mathrm{Hg}$ exposed rats (fig 1). Glomeruli showed hypercellularity, deposition of amorphous material in the mesangium, and thickening of the basal membrane. Examination with electron microscopy did not show modifications in the glomerular capillary wall, but only deposits of amorphous material in the mesangium; deposition of amorphous material and thickening of the vascular wall were found in the interstitium by light microscopy. The immunofluorescence technique showed deposition of $\operatorname{IgM}$, but not of $\operatorname{IgA}$, IgG, $C_{3}, C_{1 d}$, albumin, or fibrinogen in the glomeruli of the $\mathrm{Hg}$ exposed rats (fig 2). Light focal hydropic degeneration of the tubular cells and amorphous material in some lumens were found (by light microscopy) after $\mathrm{Hg}$ treatment (fig 3). At electron microscopy lysosomes of all the tubular cells showed a reduction of electrondensity and irregular borders, but not lysis. The acid phosphatase activity of these cells, mostly localised in the lysosomes, ${ }^{26}$ was reduced. Histopathological examination of the arteries and of the kidney showed that exposure to $\mathrm{Hg}$ induced thickening of the wall of the renal vessels and focal thickening of the middle layer of the abdominal aorta.

We found that $\mathrm{Hg}$ was accumulated much more in the kidney than in the brain and in the heart of the $\mathrm{Hg}$ exposed animals. The heart appeared to store more $\mathrm{Hg}$ than the brain (table 4).

\section{Discussion}

In this study, unlike Sprague-Dawley rats exposed to $50 \mathrm{ppm}$ of $\mathrm{Hg}$ in drinking water for 320 or 250 days, ${ }^{7-9}$ Wistar rats treated with $200 \mathrm{ppm}$ of $\mathrm{Hg}$ for 180 days showed a reduction in cardiac inotropism. The high concentrations of $\mathrm{Hg}$ found in the heart of Wistar rats treated with $200 \mathrm{ppm}$ of $\mathrm{Hg}$ may explain the reduction seen in the present experiment. In this regard, the ratio between the $\mathrm{Hg}$ stored in the heart and that accumulated in brain or kidney was three or four times higher in Wistar than in Sprague-Dawley rats. ${ }^{910}$ On the other hand, the increase in blood pressure seen in Wistar rats may be explained only by a vasoconstrictor effect of $\mathrm{Hg}$ with a consequent rise in the total peripheral resistance. This rise is likely to be related to greater release of noradrenaline from postganglionic adrenergic neurons and to baroreflex hyposensitivity, as suggested in previous studies. ${ }^{7-10}$ On the basis of these experiments, the increase in total peripheral resistance does not seem to depend on effects of $\mathrm{Hg}$ causing alterations of sympathetic nerve activity or vascular responsiveness after activation of the $\alpha_{1}-, \alpha_{2}$, and $\beta_{2}$-adrenoreceptors and $\mathrm{DA}_{2}-$ dopaminergic receptors in blood vessels. On the other hand, the cardiovascular alterations found in the Wistar rats exposed to $200 \mathrm{ppm}$ of $\mathrm{Hg}$ cannot be explained by increased reactivity to stimulation of 


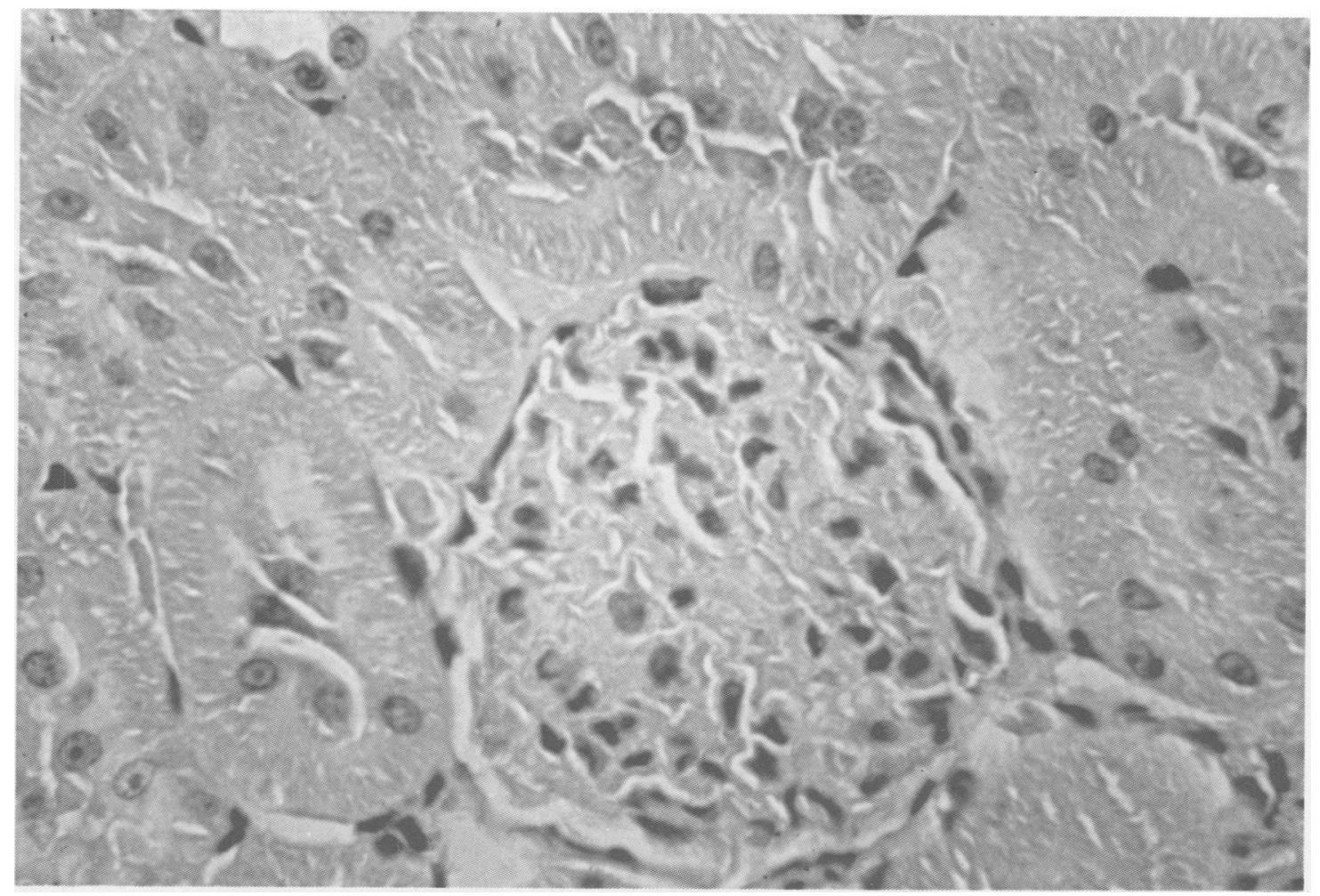

Figure 1 Glomerulus and tubular cells of an $\mathrm{Hg}$ exposed rat. The glomerulus presents hypercellularity and deposition of amorphous material in the mesangium with reduction of the vascular space. Tubular cells present hydropic degeneration. $(P A S \times 400)$.

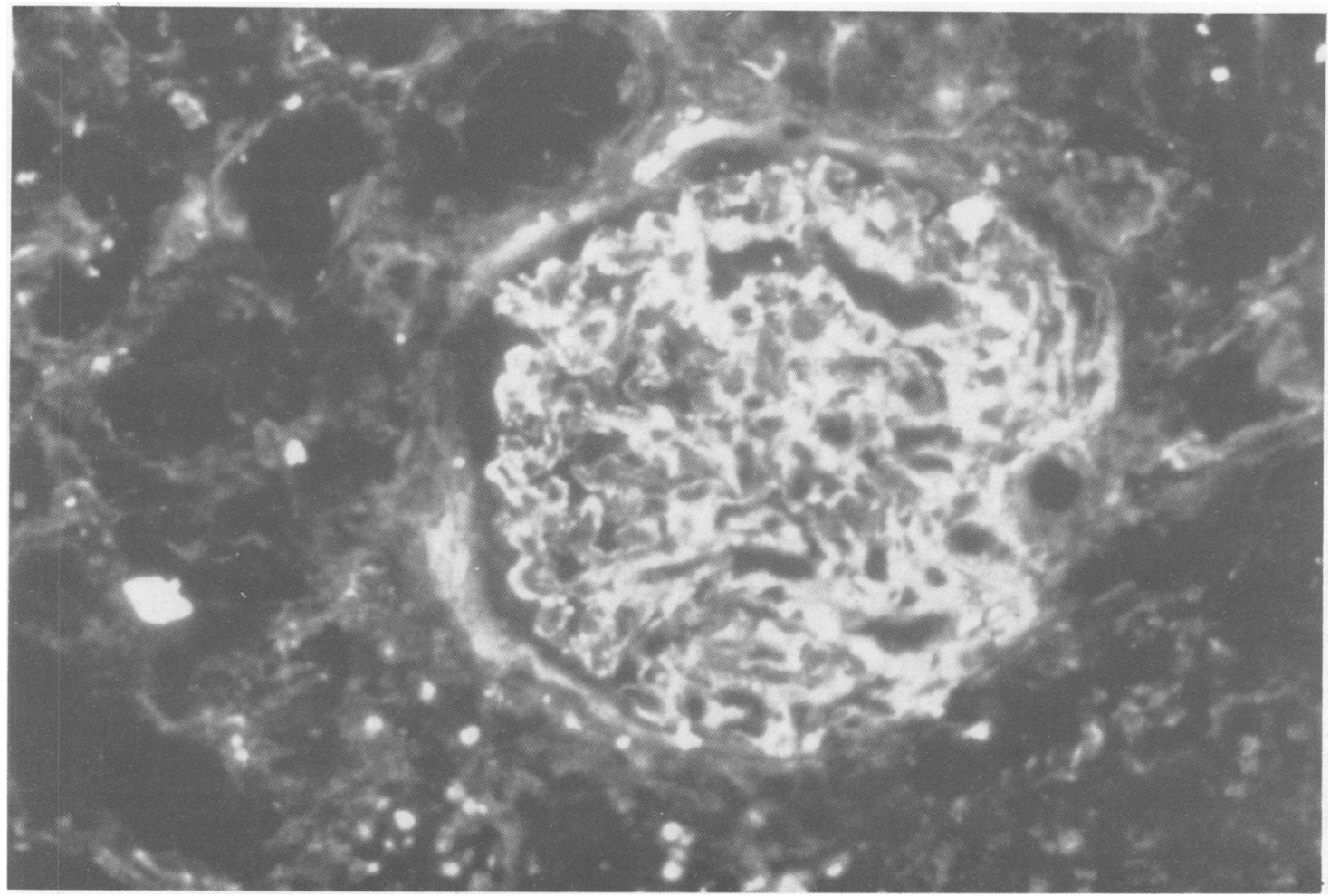

Figure 2 Renal glomerulus of an $\mathrm{Hg}$ exposed rat showing intraglomerular deposits of IgM. (immunofluorescence $\times 400$ ). 


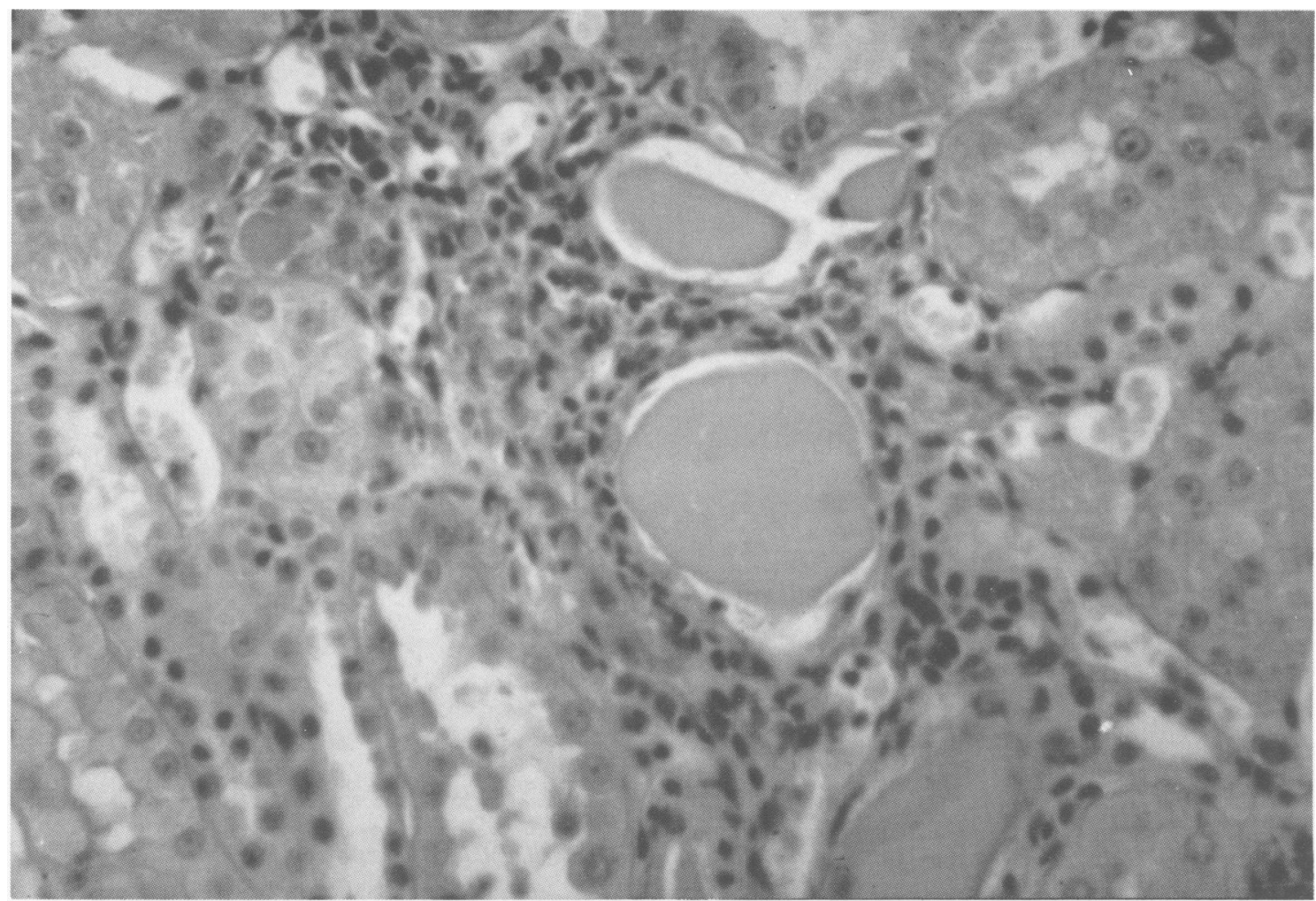

Figure 3 Proximal tubular cells of an $\mathrm{Hg}$ exposed rat showing hydropic degeneration, deposition of ialine material in lumens, and inflammatory cells (mostly lymphocytes) in the interstitium $(P A S \times 250)$.

Table 4 Concentration of $\mathrm{Hg}$ in blood, brain, heart, and kidney of rats chronically exposed to $\mathrm{Hg}$

\begin{tabular}{lcl}
\hline & $\begin{array}{l}\text { Control } \\
(\text { mean }(S E))\end{array}$ & $\begin{array}{l}\text { Exposed } \\
(\text { mean }(S E))\end{array}$ \\
\hline Blood $\mu \mathrm{g} / \mathrm{g})$ & $0.94(0.27)$ & $<0.03^{\star}$ \\
Brain $(\mu \mathrm{g} / \mathrm{g})$ & $2.27(0.73)$ & $<0.06^{\star}$ \\
Heart $(\mu \mathrm{g} / \mathrm{g})$ & $4.12(1 \cdot 16)$ & $<0.07^{\star}$ \\
Kidney $(\mu \mathrm{g} / \mathrm{g})$ & $160.25(27 \cdot 16)$ & $<0.20^{\star}$ \\
\hline
\end{tabular}

${ }^{\star} \mathrm{p}<0.05$; significantly different from control.

All values are expressed on a wet weight basis ( $n=4$ in both groups for blood and brain and $n=6$ in both groups for heart and kidney).

the peripheral $\beta_{1}$ and $\beta_{2}$-adrenoreceptors, as it was found in the Sprague-Dawley rats exposed to $50 \mathrm{ppm}$ of $\mathrm{Hg}$ for 320 or 350 days ${ }^{7-9}$ Because $\mathrm{Hg}$ was shown to reduce the availability of $\mathrm{Ca}^{2+}$ for contractile mechanisms in both cardiac and vascular myocells (by an interaction with both receptor operated $\mathrm{Ca}^{2+}$ channels and cyclic nucleotide pathways), it may be that the decrease of cardiac inotropism found in this study is the result of a local toxic effect of $\mathrm{Hg}$ that involves myocardial contractile processes. ${ }^{7-10}$

Both reduction of creatinine excretion and proteinuria found in some of the $\mathrm{Hg}$ exposed Wistar rats seem to depend upon a mild form of glomerulonephritis induced by $\mathrm{Hg}$. In this regard, rats exposed to $\mathrm{Hg}$ showed several forms of glomerulonephritis such as membranous, ${ }^{12}$ a mesangial, ${ }^{13}$ or an immune complex type of glomerulonephritis. ${ }^{15}$ The hypercellularity and deposition of amorphous material in the mesangium, without alterations in the glomerular vessels, indicate that $\mathrm{Hg}$ caused a mesangial proliferative glomerulonephritis in the Wistar rats used in this research. ${ }^{27}$ Differences in duration of exposure, doses, and routes of administration of $\mathrm{Hg}$, strains of animals, and other variables may account for the ability of $\mathrm{Hg}$ to induce various types of glomerulonephritis. On the other hand, autoimmune mechanisms involved in these glomerular lesions may also be related to the morphological alterations of lysosomes seen in the tubular cells and to reduction of the acid phosphatase activity, which is localised in these lysosomes. ${ }^{27}$ Thus as lysis of lysosomes was found in tubular cells of $\mathrm{Hg}$ exposed SpragueDawley rats, it may be that circulating $\mathrm{Hg}$ binding proteins, derived from the lysis of lysosomes, play a part in determining the different $\mathrm{Hg}$ induced immunological and pathological alterations found both in humans ${ }^{4}$ and experimental animals. ${ }^{9-1115}$ 
A surprising result of this experiment was the increase of plasma ACE activity in the presence of reduced PRA. It is possible, therefore as in lead exposed humans and laboratory animals, ${ }^{28-30}$ that $\mathrm{Hg}$ initially increases PRA and, whenever the exposure is prolonged, reduces the activity of this plasma enzyme. Moreover, considering the biochemical and functional relations between the plasma renin and urinary kallikrein systems, ${ }^{30}$ the possibility also exists that reduction of urinary kallikrein activity and reduction of PRA are interdependent. On the other hand, reduction of urinary kallikrein alone was not seen in Sprague-Dawley rats chronically exposed to $50 \mathrm{ppm}$ of $\mathrm{Hg}^{31}$ and in asymptomatic $\mathrm{Hg}$ exposed workers, ${ }^{32}$ but only in cadmium exposed rats ${ }^{33}$ and human subjects. ${ }^{32}$ Another explanation for the increase in plasma ACE activity and reduction of PRA may be derived from the recent revision of the classic concept of the circulating renin angiotensin system (RAS) ${ }^{34}$ In this respect, the most important findings are that (a) the major site of production of angiotensin I (A1) and II (A2) is peripheral tissues, (b) the primary role of the circulating RAS is that of delivering renin and angiotensinogen to tissues, and (c) in tissues (including vessel wall and kidney) there is synthesis of angiotensinogen, renin or renin-like enzymes, and ACE. It is apparent that this local production (and degradation) of $\mathrm{A} 1$ and $\mathrm{A} 2$ is subject to tissue specific mechanisms of regulation, which change local A2 concentration without reference to the plasma concentrations of renin or A2. Thus $\mathrm{Hg}$ may interfere with these local tissue specific mechanisms such as the extent of tissue uptake of renin, angiotensinogen $\mathrm{A} 1$ and $\mathrm{A} 2$, and the local tissue concentration of ACE. In other words, the effects of $\mathrm{Hg}$ on plasma ACE activity and PRA may be the result of different actions of $\mathrm{Hg}$ on plasma and tissue RAS. According to these concepts, the normal concentrations of plasma aldosterone in $\mathrm{Hg}$ exposed rats may reflect the cumulative effects of $\mathrm{Hg}$ on the adrenal glands, RAS, and renal kallikrein system (influencing both synthesis and release of aldosterone). ${ }^{30}$

This study confirms that the kidney is one of the main targets of the toxic effects seen after chronic exposure to $\mathrm{Hg}$. In particular, through different mechanisms (including those of autoimmunity), $\mathbf{H g}$ causes changes in the RAS and the kallikrein-kinin system that contribute to modify systemic haemodynamics. Experimental variables (such as dose of exposure, route of administration, duration of treatment, sex of the animals, and environmental factors) may have influenced or modulated the effects of $\mathrm{Hg}$.

We thank Mr Giuseppe Ripanti for his skilful assistance.
Requests for reprints to: Marco Carmignani, Department of Cell Biology and Physiology, Via Vetoio, 67010 Coppito, L'Aquila, Italy.

1 Gobbato F, Chiesura P. La nefropatia da piombo. Minerva Nefrologica 1968;75:12-24.

2 Buchet JP, Roels H, Bernard A, Lauwerys R. Assessment of renal function of workers exposed to inorganic lead, cadmium or mercury vapor. J Occup Med 1980;22:741-50.

3 Stonard MD, Chater BV, Duffield DP, Nevitt AL, O'Sullivan JJ, Steel GT. An evaluation of renal function in workers occupationally exposed to mercury vapor. Int Arch Occup Environ Health 1983;52:177-89.

4 Foà V, Caimi L, Amanti L. Patterns of some lysosomal enzymes in the plasma and of proteins in urine of workers exposed to inorganic mercury. Int Arch Occup Environ Health 1976;37:115-24.

5 Bernard A, Roels H, Buchet JP, Lauwerys R. Comparison by sodium dodecyl sulphate polyacrylamide gel electrophoresis of urinary proteins excreted by workers exposed to cadmium, mercury or lead. Toxicol Lett 1980;5:219-22.

6 Barregàrd L, Hultberg B, Schütz A, Sällsten G. Enzymuria in workers exposed to inorganic mercury. Int Arch Occup Environ Health 1988;61:65-9.

7 Carmignani M, Finelli VN, Boscolo P. Mechanisms in cardiovascular regulation following chronic exposure of male rats to inorganic mercury. Toxicol Appl Pharmacol 1983;69: 442-50.

8 Carmignani M, Boscolo P. Cardiovascular homeostasis in rats chronically exposed to mercuric chloride. Arch Toxicol 1984;(suppl 7):383-6.

9 Carmignani M, Boscolo P, Preziosi P. Renal ultrastructural alterations and cardiovascular functional changes in rats exposed to mercuric chloride. Arch Toxicol 1989;(suppl 13):353-6.

10 Boscolo P, Carmignani M, Giuliano G, Preziosi P. Peripheral catecholaminergic mechanisms and baroreflex pathways are involved in vascular and cardiac effects of long-term exposure to inorganic mercury in rats. In: Strano A, Novo S, eds. Advances in vascular pathology. Amsterdam: Elsevier Science Publishers 1989:1061-6.

11 Boscolo P, Carmignani M, Artese L, et al. New experimental studies on the cardiovascular effects of chronic mercury exposure. In: Anke N, Baumann W, Bräunlich H, Brücker C, Groppel B, Grün M, eds. Sixth international trace elements symposium 1989. Jena: Wissenschaftliche Publikationen der Friedrich-Schiller-Universität, 1989:1638-46.

12 Bariety J, Druet P, Laliberte F, Sapin C. Glomerulonephritis with $\gamma$ and $\beta$ 1C-globulin deposits induced in rats by mercuric chloride. Am J Pathol 1971;65:293-302.

13 Makker SP, Aikawa M. Mesangial glomerulopathy with deposition of IgG, IgM and C3 induced by mercuric chloride. A new model. Lab Invest 1979;41:45-50.

14 Hirsch F, Couderc J, Sapin C, Fournier G, Druet P. Polyclonal effect of $\mathrm{HgCl}_{2}$ in the rat; its possible role in an experimental autoimmune disease. Eur J Immunol 1982;12:620-5.

15 Druet P, Pelletier R, Hirsch F, et al. Mercury-induced autoimmune glomerulonephritis in animals. Contributions to Nephrology 1988;61:120-30.

16 Crawford W, Teamy RJ, Hawthorne EW. Increased myocardial contractility during the initial period of hypertension in dogs following renal artery constriction. Federation Proceedings. 1973;32:351.

17 Davidson DM, Covell JW, Mallock CI, Ross J, Jr. Factors influencing indices of left ventricle contractility in the conscious dog. Cardiovasc Res 1974;8:299-312.

18 Freedlender AE, Goodfriend TL. Renin and the angiotensins. In: Jaffe BM, Behrman HR, eds. Methods of hormone radioimmunoassay. New York: Academic Press 1979:889-913.

19 Volpe AR, Porcelli G, Di Iorio M. Determination of kininase I and II activities in human urine by HPLC. $J$ Chromatogr 1989;414:427-31.

20 Abraham GE, Garza AR, Manlimos FS. Radioimmunoassay of steroids. In: Abraham GE, ed. Handbook of radioimmunoassay. New York: Dekker M, Inc 1977:591-618.

21 Morita T, Kato H, Iwanaga S, Takada K, Kimura T, Sakakibara $\mathrm{S}$. New fluorogenic substrates for $\alpha$-thrombin, factor $\mathbf{X a}$, kallikreins and urokinase. J Biochem Tokio 1977;82:1495-8.

22 Gomori G. Microscopic histochemistry: principles and practice. 
Chicago: The University of Chicago Press, 1952.

23 Paul WE. Fundamental immunology. 2nd edition. New York: Raven Press, 1989.

24 Boscolo P, Carmignani M, Sacchettoni-Logroscino G, et al. Ultrastructure of the testis in rats with blood hypertension induced by long-term lead exposure. Toxicol Lett 1988;41:129-37.

25 Krause LA, Henderson R, Shotwell HP, Culp DA. The analysis of mercury in urine, blood, water and air. Am Ind Hyg Assoc J 1971;32:331-7.

26 Thorlacius-Ussing O, Møller Graabaek P. Simultaneous ultrastructural demonstration of heavy metals (silver, mercury) and acid phosphatase. Histochem $J$ 1986;18:639-46.

27 Glassock RJ, Cohen AH. Immunologically mediated renal disease. In: Klahr S, Massry S, eds. Contemporary nephrology, Vol 3. New York: Plenum Medical Book Company, 1985.

28 Boscolo P, Carmignani M. Neurohumoral blood pressure regulation in lead exposure. Environ Health Perspect 1988;78:101-6.

29 Victery $M$. Evidence for effects of chronic lead exposure on blood pressure in experimental animals: an overview. Environ Health Perspect 1988;78:71-6.

30 Scicli AG, Carrettero AO. Renal kallikrein-kinin system. Kidney Int 1986;29:120-30.

31 Boscolo P, Carmignani M, Menini E, et al. Urinary vanillylmandelic acid and kallikrein and cardiovascular parameters in rats chronically exposed to different toxic metals. Acta Medica Romana 1985;23:208-15.

32 Roels HA, Lauwerys R, Buchet JP, Bernard AM, Lijnen P, Van Houte G. Urinary kallikrein activity in workers exposed to cadmium, lead, or mercury vapour. $\mathrm{Br} J$ Ind Med 1990;47:331-7.

33 Boscolo P, Porcelli G, Carmignani M, Finelli VN. Urinary kallikrein and hypertension in cadmium-exposed rats. Toxicol Lett 1981;7:189-94.

34 Campbell DJ. Circulating and tissue angiotensin systems. J Clin Invest 1987;79:1-5.

Accepted 15 July 1991

\section{Vancouver style}

All manuscripts submitted to the $B r J$ Ind Med should conform to the uniform requirements for manuscripts submitted to biomedical journals (known as the Vancouver style).

The $\mathrm{Br} J$ Ind Med, together with many other international biomedical journals, has agreed to accept articles prepared in accordance with the Vancouver style. The style (described in full in $\mathrm{Br}$ Med J, 24 February 1979, p 532) is intended to standardise requirements for authors.

References should be numbered consecutively in the order in which they are first mentioned in the text by Arabic numerals above the line on each occasion the reference is cited (Manson' confirmed other reports ${ }^{2-5} \ldots$.). In future references to papers submitted to the $\mathrm{Br} J$ Ind Med should include: the names of all authors if there are six or less or, if there are more, the first three followed by et al; the title of journal articles or book chapters; the titles of journals abbreviated according to the style of Index Medicus; and the first and final page numbers of the article or chapter.

Examples of common forms of references are:

1 International Steering Committee of Medical Editors. Uniform requirements for manuscripts submitted to biomedical journals. Br Med J 1979;1:532-5.

2 Soter NA, Wasserman SI, Austen KF. Cold urticaria: release into the circulation of histamine and eosino-phil chemotactic factor of anaphylaxis during cold challenge. N Engl J Med 1976;294:687-90.

3 Weinstein L, Swartz MN. Pathogenic properties of invading micro-organisms. In: Sodeman WA Jr, Sodeman WA eds. Pathologic physiology: mechanisms of disease. Philadelphia: W B Saunders, 1974:457-72. 